\title{
XXXII Letnia Szkoła Młodych Pedagogów:Kultura szkoły: Czym ona jest? Jak ja badać i o niej pisać? Zielona Góra-Lagów Lubuski, 17-22 września 2018 r.
}

$* * *$

Pisząc te słowa w pamięci mamy pożegnanie Pani Profesor, która opuściła obrady trzeciego dnia trwania Szkoły. Pożegnanie - tak symboliczne i wzruszające - pozostanie w naszych sercach pięknym wspomnieniem.

$* * *$

XXXII Letnia Szkoła Młodych Pedagogów była pod wieloma względami wyjątkowa. Przede wszystkim ze względu na jubileusz 25-lecia kierowania naukowego letnimi szkołami przez prof. dr hab. Marię Dudzikową, co dla wielu osób i instytucji stanowiło niepowtarzalną okazję do wyrażenia podziękowań za niestrudzoną troskę o rozwój naukowy młodych adeptów pedagogiki. Jubileusz ten, w obliczu ciężkiej choroby Pani Profesor, stał się dla nas wszystkich ostatnim, serdecznym pożegnaniem z naszą Mistrzynią i Przyjaciółką Młodych. Po wtóre, dla tegorocznych Gospodarzy oraz wielu uczestników LSMP była to również sentymentalna podróż do wspomnień sprzed 14 lat, gdy w tym samym miejscu odbyła się XVIII Letnia Szkoła, poświęcona rozważaniom dotyczącym nowoczesnej szkoły, organizowana przez zielonogórskie środowisko akademickiej pedagogiki.

Tegoroczna Letnia Szkoła Młodych Pedagogów odbyła się w dniach 17 22 września 2018 w Łagowie Lubuskim. Wydarzenie to zostało zorganizowane pod auspicjami Komitetu Nauk Pedagogicznych Polskiej Akademii Nauk. Rolę Gospodarza tegorocznej Szkoły pełnił Wydział Pedagogiki, Psychologii i Socjologii Uniwersytetu Zielonogórskiego reprezentowany przez dziekana dra hab. Marka Furmanka, prof. UZ. Kierownictwo naukowe sprawowała po raz 25. prof. dr hab. Maria Dudzikowa. O wysoki poziom merytoryczny Szkoły dbała zastępczyni kierownik naukowej dr hab. Ewa Bochno, prof. UZ. Obowiązki sekretarza naukowego XXXII LSMP pełniła dr Magdalena Zapotoczna, Prezydentka Forum Młodych Pedagogów w kadencji 2017/2018. Nad organizacją i przebiegiem Szkoły czuwał zespół organizacyjny w składzie: mgr Astina Koch, mgr Emilia Kuligowska, mgr Barbara Walas, mgr Klaudia Żernik, mgr Grzegorz Hryniewicz, mgr Sławomir Sobański, których działania wspierały mgr Karolina Silna i mgr Elżbieta Staniec. W tegorocznej Szkole udział wzięło 38 młodych uczestników, w tym 23 doktorów i 16 magistrów, oraz 25 Mistrzów - profesorów i zaproszonych gości. 
Specyfikę tegorocznej Letniej Szkoły nadał jej temat: Kultura szkoły: Czym ona jest? Jak ja badać i o niej pisać?. Zgodnie z informacją zamieszczoną w zaproszeniach - interesowała nas szkoła jako instytucja osadzona w określonej kulturze i jednocześnie stanowiąca swoistą kulturę, w której jest zanurzona i którą tworzy wspólnota szkolna. Naukowe dociekania poświęcone były interdyscyplinarnej diagnozie szkoły jako organizacji, w której odzwierciedla się to, co niesie jej otoczenie, a więc zjawiska i procesy pochodzące z zewnątrz, ale też szkoły, która stanowi określony zespół wartości, tradycji, dążeń, przekonań, postaw będących jej istotą i jednocześnie decydujących o jej społecznym klimacie, a zatem warunkach i relacjach w niej doświadczanych, tym, co jest wewnątrz.

W trakcie obrad problematyka została uszczegółowiona wokół dwóch zagadnień. Po pierwsze: dwie opcje teoretyczne badania kultury szkoły (jako zasób i jako proces) i co z nich wynika dla epistemologii i metodologii oglądu codzienności szkolnej? Po drugie: jak opisywać, analizować, interpretować sceny i zdarzenia z życia szkolnej codzienności?

To wyjątkowe wrześniowe spotkanie naukowe zyskało na przestrzeni ponad 30 lat swojego istnienia „status (...) instytucji, która poprzez inwestowanie w człowieka, jego wiedzę i umiejętności sprzyja budowaniu wspólnoty opartej na zaufaniu i zaangażowaniu jej uczestników i twórców jednocześnie" (E. Bochno, A. Korzeniecka-Bondar, Naukowa wspólnota uczących się, s. 12). W myśl metafory „latającego uniwersytetu” każdego roku inna uczelnia gości młodych badaczy oraz znawców danego tematu i koncentruje swoje wysiłki na stworzeniu optymalnych warunków sprzyjających dzieleniu się własnym dorobkiem naukowym oraz przestrzeni do spotkań Mistrzów z uczniami.

Jak co roku, specyfika Letniej Szkoły sprzyjała autentycznej integracji środowiska akademickiego i podejmowaniu dialogu na rzecz (współ)tworzenia naukowej wspólnoty i zacieśniania więzi międzypokoleniowych. Wykłady Profesorów i wystąpienia Młodych były okazją do prezentowania bogactwa sposobów pojmowania i uprawiania pedagogiki, szkołą myślenia i określania tożsamości naukowej, a także ukierunkowywania własnych poszukiwań badawczych. Dla młodej kadry akademickiej LSMP stanowiła okazję do wymiany oraz upowszechniania wyników badań oraz prezentacji własnych przemyśleń wypracowanych w ramach przygotowywanych prac doktorskich lub habilitacyjnych i poddawania ich konstruktywnej krytyce.

Uroczysta ceremonia otwarcia odbyła się w poniedziałek, 17 września 2018, w sali konferencyjnej hotelu Leśnik w Łagowie Lubuskim. Inauguracji tygodniowych obrad dokonali: prof. dr hab. Bogdan Śliwerski - Przewodniczący Komitetu Nauk Pedagogicznych PAN, prof. dr hab. Maria Dudzikowa - Naukowa Kierownik LSMP oraz zastępczyni kierownik naukowej dr hab. Ewa Bochno, prof. UZ. W imieniu władz wydziału gości powitał dziekan dr hab. Marek Furmanek, 
prof. UZ. Kolejnym stałym punktem programu Szkoły było wręczenie dyplomów Strzat w 10, które otrzymali: prof. Bogusław Śliwerski, prof. Zbigniew Kwieciński, dr hab. Ewa Bochno prof. UZ, dr hab. Zygmunt Kalinowski, dr Jolanta Sajdera oraz dr Magdalena Zapotoczna. Następnie zgodnie z tradycją nastąpiło symboliczne przekazanie insygniów władzy - pałeczki i kociałki - gospodarzom XXXIII LSMP odbywającej się w 2019 roku w Olsztynie: dziekanowi Wydziału Nauk Społecznych dr. hab. Sławomirowi Przybylińskiemu, prof. UWM oraz sekretarz dr Katarzynie Białobrzeskiej. Wprowadzenia merytorycznego dokonała kierownik naukowa LSMP prof. Maria Dudzikowa, która po krótkim nakreśleniu problematyki Szkoły, zaakcentowała znaczenie i potrzebę budowania kapitału ludzkiego i społecznego w środowisku naukowym, nawiązując tym samym do jubileuszowych publikacji LSMP przy KNP PAN.

W drugiej części uroczystości prof. Bogusław Śliwerski zainaugurował świętowanie 25 rocznicy kierowania LSMP przez prof. Marię Dudzikową. W uznaniu wyjątkowych zasług dla nauki, oświaty i kształcenia kadr pedagogicznych prof. Śliwerski wręczył medal KNP PAN za zasługi dla rozwoju polskiej pedagogiki. Dziękując za ćwierć wieku wyjątkowej pracy naukowo-badawczej i dydaktycznej powiedział: „Wszystko to, czym każdy z nas został obdarzony przez Panią Profesor, jest $\mathrm{z}$ jednej strony niewymowne, jakże trudne do wyrażenia ze względu na procesy dojrzewania $w$ nas ponadczasowych ziaren prawdy, dobra i piękna, a $\mathrm{z}$ drugiej strony staje się moralnym zobowiązaniem do dzielności w nieposłuszeństwie wobec wszystkiego, co może skutkować pozorem, manipulacją czy post-prawdą ze strony podmiotów akademickich, oświatowych czy politycznych"2.

W dowód uznania szczególnych zasług na rzecz rozwijania nauk pedagogicznych oraz popularyzacji ich osiągnięć prof. Maria Dudzikowa została także uhonorowana medalem Polskiego Towarzystwa Pedagogicznego. W imieniu przewodniczącej prof. dr hab. Joanny Madalińskiej-Michalak oraz członków Towarzystwa gratulacje i życzenia z okazji wyjątkowego jubileuszu złożył honorowy przewodniczący PTP prof. dr hab. Zbigniew Kwieciński oraz przewodnicząca oddziału terenowego PTP w Zielonej Górze dr hab. Inetta Nowosad, prof. UZ. Uroczystego i podniosłego nastroju dopełniły listy gratulacyjne, które wraz z naręczami kwiatów i symbolicznymi upominkami stanowiły wyraz szacunku, wdzięczności i życzliwej pamięci. W podziękowaniu za wieloletnie zaangażowanie i wsparcie w rozwoju, jakiego doświadczyły pokolenia młodych naukowców odczytano listy skierowane przez przedstawicieli uczelni i władz wydziałów reprezentujących społeczności wielu ośrodków akademickich w Polsce, m.in. Wydział Studiów Edukacyjnych Uniwersytetu im. Adama Mickiewicza w Poznaniu, Wydział

\footnotetext{
2 Źródło: http://sliwerski-pedagog.blogspot.com/2018/09/dwadziescia-piec-lat-kierowania-przez. html
} 
Nauk Pedagogicznych Uniwersytetu Kardynała Stefana Wyszyńskiego w Warszawie, Wydział Nauk Społecznych Katolickiego Uniwersytetu Lubelskiego im. Jana Pawła II, Wydział Nauk Społecznych Uniwersytetu Warmińsko-Mazurskiego w Olsztynie, Wydział Pedagogiki i Psychologii Uniwersytetu w Białymstoku, Wydział Pedagogiki, Psychologii i Socjologii Uniwersytetu Zielonogórskiego, Wydział Nauk Pedagogicznych Uniwersytetu Mikołaja Kopernika w Toruniu oraz Wydział Etnologii i Nauk o Edukacji Uniwersytetu Śląskiego w Cieszynie.

Zwieńczeniem części inauguracyjnej, a zarazem naukowym otwarciem XXXII LSMP był wykład wygłoszony przez prof. dra hab. Zbigniewa Kwiecińskiego, dra h.c. multi pt. Utrata złudzeń edukacji publicznej. Stracona szansa, fatalne dziedzictwo, iskry nadziei. Prelegent postawił pytanie czy w sytuacji powszechnego oportunizmu, pryncypialności i patologizacji postaw obywatelskich szkoła i pedagodzy mogą temu przeciwdziałać? Profesor, nawiązując do raportu PAN Polska 2050 wskazał, że spełniają się najbardziej pesymistyczne prognozy wskazujące na podważanie zasad demokracji społeczeństwa, wolności i wiarygodność mediów czy zatracenia troski o dobro wspólne.

Podsumowaniem, nieoznaczającym końca dnia, była prezentacja pt. Odradzanie tradycji winiarstwa lubuskiego połączona z degustacją wina, przygotowana przez Mariusza i Karolinę Pacholak, właścicieli winnicy Cantina. Intencją organizatorów było przybliżenie uczestnikom wizerunku regionu i zwrócenie uwagi na ożywienie dawnych tradycji winogrodnictwa, które kreują lokalną tożsamość i historię ziemi lubuskiej.

Tuż po prelekcji uczestnicy zostali obdarowani nadesłanymi przez wydawnictwa publikacjami książkowymi. Tradycją Szkół jest nieodpłatne przekazywanie uczestnikom książek publikowanych przez najbardziej liczące się wydawnictwa w Polsce. Dzięki temu młodzi pracownicy nauki powiększają swoje zbiory biblioteczne, jednocześnie dzieląc się nimi ze współpracownikami i studentami.

Dzień zakończyła kolacja przy ognisku, podczas której goście mieli możliwość lepszego poznania się, wymiany doświadczeń i poglądów, będących źródłem wzajemnych inspiracji. Wieczorne spotkanie w plenerze stanowiło także okazję do zainicjowania pierwszych indywidualnych konsultacji z Mistrzami w odrobinę mniej sformalizowanych warunkach.

W kolejnych dniach trwania Szkoły problematykę uszczegóławiano w kilku, wypróbowanych już formach, a więc poprzez wykłady, dyskusje panelowe, warsztaty i prezentacje naukowe zaproszonych gości - autorytetów w dziedzinie nauk humanistycznych i społecznych, rozmowy i konsultacje znimi, problemowe seminaria w małych grupach oraz wystąpienia i prezentacje dorobku młodej kadry pedagogicznej, określanych humorystycznie Giełda (p)różności.

Cztery dni intensywnych obrad i wymiany myśli zapoczątkowały wykłady Mistrzów. Prof. dr hab. Bogusław Śliwerski, dr h.c. multi wprowadził uczestni- 
ków LSMP w zagadnienia poświęcone: Kulturze szkoły czy klasy szkolnej? Z doświadczeń minionego eksperymentu. Wykład rozpoczął od scharakteryzowania cech kultury szkoły. Następnie profesor, odwołując się do metafory „panoptycznej szkoły", wskazał na monogamiczny charakter kultury szkoły i jej centralistyczny sposób zarządzania. Panoptikom zaprojektowany przez filozofa utylitarystę Jeremy'ego Benthama stał się symbolem permanentnej inwigilacji i wizją współczesnej władzy w instytucjach stosujących nadzór. Profesor, odwołując się do prowadzonych przez siebie od ponad 25 lat badań nad demokratyzacją systemu szkolnego, podjął próbę analizy faktów i zjawisk społeczno-wychowawczych szkoły i jej form działalności w kontekście intensywnych przemian społeczno-kulturowych. W swoich rozważaniach prelegent wskazał także przykłady alternatywnych szkół w Polsce, jak choćby Zespołu Szkół Społecznych „Bednarska” w Warszawie, nieistniejąca już Szkoła Laboratorium Toruniu czy Wrocławska Szkoła Przyszłości we Wrocławiu.

Profesor Uniwersytetu Zielonogórskiego dr hab. Inetta Nowosad w wystąpieniu zatytułowanym $Z$ badań nad kultura szkoły. W kalejdoskopie analiz i interpretacji dokonała przeglądu światowych badań nad kulturą szkoły, zwracając uwagę słuchaczy na słabo rozwinięty w przeciwieństwie do krajów anglosaskich nurt badań w Polsce. Prelegentka w swojej narracji wykorzystała znakomicie dobraną metaforę kalejdoskopu i wręczyła symboliczny kalejdoskop prof. Marii Dudzikowej. Profesor Nowosad wyeksponowała pola problemowe kategorii kultury szkoły obecne w debatach polityczno-oświatowych i zwróciła uwagę na różnorodność rozumienia kultury szkoły i jej poziomów z perspektywy różnych dyscyplin naukowych oraz podejść badawczych zilustrowanych za pomocą metafory kultury szkoły jako cebuli, sieci, drzewa i góry lodowej. W swoim wystąpieniu zielonogórska pedagog wskazała także normatywny projekt zmieniania i kształtowania kultury szkoły na poziomie całego systemu oświatowego.

Popołudniowy blok wykładów mistrzowskich otworzyła prof. dr hab. Dorota Klus-Stańska, prezentując referat pt. Kultury dydaktyczne. Światy znane i niezna$n e$. Po analizie wybranych paradygmatów dydaktyki szkolnej badaczka wykazała, że w Polsce od lat 70. XX wieku dominuje model dydaktyki postsowieckiej zorientowanej na pomiar i selekcję uczniów. W opinii gdańskiej pedagog, neurodydaktyka stanowi przykład „nowoczesnego” podejścia do edukacji, którego elementy próbuje się często bezrefleksyjnie i fragmentarycznie zaadaptować do warunków polskiej szkoły.

Wykłady mistrzowskie drugiego dnia obrad zakończyło wystąpienie dr Urszuli Markowskiej-Manista pt. Kolonialne i postkolonialne kultury szkoły w Afryce Środkowej. Z badań terenowych, która podzieliła się rezultatami swoich poszukiwań etnopedagogicznych dotyczących sytuacji edukacyjnej dzieci należących do grupy etnicznej Ba'Aka. W referacie prelegentka wskazała na istnienie tra- 
dycyjnej edukacji leśnej i nowoczesnej edukacji szkolnej, która skutkuje dywergencją w funkcjonowaniu społecznym Ba'Aka oraz doświadczaniem dylematów codzienności wynikających z „uwięzienia” między światem tradycji i światem cywilizacji.

Trzeciego dnia Szkoły ożywioną dyskusję wywołał wykład prof. dr hab. Barbary Fatygi pt. Sposób rozumienia kultury jako kontekst stylu życia. Swoje rozważania badaczka rozpoczęła od odwołania do antropologicznej definicji kultury, by następnie zilustrować świat kultury młodzieżowej i kryzys szkolnictwa wyższego. W opinii warszawskiej socjolog kultura wysoka straciła aktualnie swoją moc osobotwórczego wpływu na młode pokolenia. Dominuje kultura popularna oraz tendencja kryzysowa, która wyraża się w narastaniu dystansu pomiędzy zobiektywizowanymi systemami kultury a wiedzą potoczną.

Wystąpienie prof. dr hab. Beaty Przyborowskiej pt. Kultura szkoły sukcesu. Blaski i cienie na przykładzie GiLA Toruń miało formę panelu połączonego z dyskusją, w którym udział wzięli dyrektor szkoły mgr Arkadiusz Stańczyk oraz jej absolwentka dr Iwona Murawska. Istniejąca od 20 lat szkoła finansowana z subwencji oświatowej jest placówką dla wybitnie zdolnych uczniów. Dyskutanci zgodnie przyznali, że wysoka pozycja w rankingach, autorskie metody i program nauczania, zajęcia w laboratoriach i salach Uniwersytetu Mikołaja Kopernika w Toruniu przyciągają młodych ludzi. Początek nowej reformy edukacyjnej, która zamknie gimnazjum, zbiegnie się z 20-leciem szkoły.

Dr hab. Dorota Bogusława Gołębniak, prof. Collegium Da Vinci swój wykład pt. Badania kultury nauczania. Co z normatywnościa? rozpoczęła od pytań o puryzm metodologiczny, granice eklektyzmu metodologii badań społecznych i prawomocność łączenia ze sobą paradygmatów (oraz metod do nich należących) o odmiennych założeniach ontologicznych i epistemologicznych. Badaczka przybliżyła słuchaczom badania etnograficzne w pedagogice i wskazała na możliwość prowadzenia dzięki nim holistycznej i indukcyjnej analizy kultury życia codziennego.

W swoim wystąpieniu pt. Budowanie kultury szkoły na przykladzie Szkoty Laboratorium $w$ Toruniu. $Z$ doświadczeń zatożyciela i dyrektora prof. dr hab. Aleksander Nalaskowski dokonał interesującej retrospekcji. Rozważania poprzedzone zostały kontestacją możliwości jednoznacznego zdefiniowania fenomenu kultury szkoły. Prelegent porównał szkołę do akwarium, mozaiki różnych stylów życia, która może przygotować uczniów do „wypłynięcia na szerokie wody”. W oparciu o materiał wizualny profesor w autobiograficznej narracji przybliżył słuchaczom dylematy i doświadczenia ilustrujące historię i działalność autorskiej Szkoły Laboratorium.

Ostatniego dnia obrad swoimi refleksjami dotyczącymi Wrocławskiej Szkoły Przyszłości podzielił się jej założyciel prof. dr hab. Ryszard Łukaszewicz. Wy- 
stąpienie zatytułowane Wrocławska Szkoła Przyszłości - Ścieżka praktykowania marzeń - Ku trafnej utopii zawierało materiały audiowizualne dokumentujące ponad 20-letnią historię alternatywnej szkoły podstawowej we Wrocławiu. Zdaniem profesora: „,szkoła była otwieraniem drogi w przyszłość, a jednocześnie próbą jej stwarzania". Marzenia o urzeczywistnieniu utopijnej wizji edukacji - zorientowanej na rozwijanie wyobraźni, budzenie wrażliwości i wspieranie kreatywności - budziły pasję, uczyły uporu i cierpliwości. W swojej wypowiedzi profesor wskazał również cechy dobrego nauczyciela, a więc osoby posiadającej ,zdolną głowę, magię rąk, tęsknotę artystyczną duszy oraz umiejętność stawania się sobą i uczenia tego innych".

Inspiracji do krytycznej refleksji nad własnym oglądem kultury szkoły przez młodych badaczy dostarczyło wystąpienie prof. dr hab. Marii Czerepaniak-Walczak poświęcone Emancypacji codzienności szkolnej i przez codzienność. Kultura szkoły została ukazana z perspektywy procesu jej emancypacji z uwzględnieniem specyficznych dla niej symboliki i języka. Prelegentka, posługując się określeniem ,gramatyka szkoły”, analizowała trwałość i dynamikę kultury instytucji edukacyjnej oraz jej kontekst. Szkoła, będąc integralną częścią życia społecznego, zanurzona jest w kulturze masowej i świecie wirtualnym. Znormalizowane praktyki szkolne, takie jak klasyfikowanie uczniów, podział czasu i przestrzeni czy wiedzy na przedmioty pozwalają organizować szkołę w sposób analogiczny do tego, w jaki sposób gramatyka reguluje wzorce językowe.

Intelektualne dysputy zakończyło wystąpienie dr hab. Ewy Bochno, prof. UZ, pt. Kultura szkoły jako dobra wspólne. Konieczność - możliwość. Zielonogórska pedagożka przyjęła założenie, że warunkiem istnienia kultury są dobra wspólne i poczucie wspólnoty, z kolei dobro wspólne traktować można dwojako. Pierwszy aspekt oznacza dobro postrzegane przez członków społeczeństwa jako coś rzeczywistego, dostępnego, w którym i poprzez które jednostka ma możliwość bycia lepszym. W tym rozumieniu kultura - obejmująca domenę wartości, idei normatywnych i obyczajów - nadaje znaczenie życiu człowieka, grupy i całego społeczeństwa. Drugi aspekt ujmuje dobro wspólne jako coś szczególnego, co ludzie we własnym mniemaniu mają ze sobą wspólnego, a zatem także przyczynia się do tworzenia wspólnoty. Interakcje zachodzą nie tylko wśród ludzi, lecz także między ludźmi a przedmiotami, budynkami.

Obok wykładów mistrzowskich niezwykle inspirujące były warsztaty i prezentacje naukowe prowadzone przez zaproszonych gości. W ramach seminariów tematycznych młodzi uczestnicy mieli możliwość skonsultowania swoich pomysłów badawczych i praktycznego spojrzenia na omawiane zagadnienia. Na tegorocznej Szkole warsztaty przygotowali i przeprowadzili (w kolejności chronologicznej): dr hab. Agnieszka Nowak-Łojewska, prof. UG (Fenomenografia jako strategia badań jakościowych), dr Krzysztof Sawicki (Nowe technologie badania 
kultury), dr hab. Inetta Nowosad, prof. UZ („Poznawanie cech kultury szkoty”), dr Beata Zamorska (Potencjat zmiany kultury szkoły w badaniach interwencyjnych) oraz dr Maciej Ciechomski (Budowanie kultury empatii w szkole).

Ważnym punktem tygodniowych obrad jest Gietda (p)różności, czyli czas prezentacji własnych przemyśleń i wyników badań przez młodych. Spośród zgłoszonych propozycji komisja zakwalifikowała 15 wystąpień młodych pedagogów reprezentujących 22 ośrodki akademickie w Polsce. W ocenie tekstów uwzględniano poziom merytoryczny, strukturę wystąpienia oraz poprawność językową. Każde 10-minutowe wystąpienie wieńczyła merytoryczna dyskusja. Najlepsze wystąpienia, wybrane drogą demokratycznego głosowania przez audytorium, nagrodzone zostały dyplomem i możliwością opublikowania adaptacji tekstu w „Roczniku Pedagogicznym”. Po uzyskaniu pozytywnej recenzji zaprezentowane w czasie LSMP referaty ukazują się w „Zeszytach Forum Młodych Pedagogów przy KNP PAN".

W czasie tegorocznej Szkoły swoje referaty zaprezentowali (wymienieni w kolejności alfabetycznej): dr Maksymilian Chutorański (Usz), dr Alicja Korzeniecka-Bondar (UWB), dr Anna Kowal-Orczykowska (PWSZ w Legnicy), dr Grzegorz Kozdraś (UO), dr Aneta Makowska (Usz), dr Justyna Ratkowska-Pasikowska (UŁ), dr Zofia Remiszewska (UO), dr Arleta Suwalska (UŁ), dr Bożena Tołwińska (UWB); Joanna Giebułtowska (APS), mgr Violetta Jaśkiewicz (DSW), mgr Celina Kamecka-Antczak(UMK), mgr Anna Nowak (UMK), mgr Mateusz Szafrański (UMK) i mgr Barbara Walas (UZ).

$\mathrm{Na}$ podkreślenie zasługuje fakt, iż charakterystycznym elementem letnich szkół są programowo i strukturalnie wbudowane relacje Młodych z Mistrzami. Adepci sztuki pedagogicznej mogli konsultować swoje zamierzenia badawcze w czasie indywidualnych lub zespołowych spotkań z profesorami - specjalistami w danej dziedzinie. Dyskusje inicjowane przez młodych dotyczyły zarówno projektowania badań, doboru źródeł, jaki i sztuki czytania tekstów czy doskonalenia warsztatu pisarstwa naukowego.

Tradycją LSMP jest wizyta w murach uczelni gospodarzy Szkoły, która odbywa się czwartego dnia tygodniowych obrad. W czwartek, 20 września 2018, inauguracja dnia gospodarzy miała miejsce w gmachu Biblioteki Uniwersyteckiej, w której uczestnicy zostali powitani przez władze Uniwersytetu Zielonogórskiego - prorektora ds. Studenckich prof. dra hab. Wojciecha Strzyżewskiego, dziekana Wydziału Pedagogiki, Psychologii i Socjologii dra hab. Marka Furmanka, prof. UZ oraz zastępcę dyrektora Instytutu Pedagogiki dr hab. Marzennę Magdę-Adamowicz, prof. UZ.

Po prezentacji uczelni, wydziału i instytutu uczestnicy wysłuchali wykładu zielonogórskiego socjologa dra hab. Mariusza Kwiatkowskiego, prof. UZ pt. „Żywe pomosty” pod presja izolacjonizmu. Zarys koncepcji. Na początku swojego 
wystąpienia prelegent nakreślił główne założenia izolacjonizmu - strategii działania w polityce zagranicznej zakładającej odrzucenie lub ograniczenie stosunków z innymi krajami bądź - w swej najmniej zradykalizowanej odsłonie - okazanie braku zainteresowania przymierzami międzynarodowymi oraz sprawami innych krajów. W obliczu aktualnych wydarzeń, jak choćby kryzysu migracyjnego w Europie, separatyzm i alienacja stanowi temat podejmowanych $\mathrm{w}$ przestrzeni publicznej debat. W dalszej części wykładu profesor wskazał subiektywnie dobrane przykłady ludzi dialogu, „żywych pomostów”, których działalność jest świadectwem przezwyciężania podziałów, pozwala tworzyć kulturę życzliwości i zrozumienia oraz budować wspólnotę ponad podziałami.

Po obiedzie goście mieli możliwość wzięcia udziału w wybranych warsztatach prowadzonych przez pracowników wydziału: dr Edytę Mianowską (Dane $w$ zasięgu ręki. O bazach danych $w$ Internecie), dra Jacka Jędryczkowskiego (YouTube Analytics jako narzędzie badawcze pedagoga) i dra Jarosława Wagnera (Kształcenie na odległość - narzędzia wspierające). Drugą, popołudniową część pobytu w Zielonej Górze wypełnił spacer po deptaku, wizyta w podziemiach miejskiego ratusza w winiarni Bachus oraz seans w Planetarium Wenus Centrum Nauki Keplera, do którego uczestnicy zostali przewiezieni miejskim autobusem elektrycznym. Kolację w klimatycznej Palmiarni Zielonogórskiej uświetnił recital dra Andrieja Kotina - wyjątkowe spotkanie artystyczne łączące w sobie elementy piosenki literackiej, poetyckiej i folk-rockowej.

Tydzień intensywnej pracy zwieńczyła pożegnalna kolacja o wręcz rytualnym charakterze $-z$ wpisanymi na stałe zwyczajami, tradycjami i obrzędami. Pierwszym punktem wieczoru było wręczenie nagród audytorium. W kategorii najlepsze wystąpienie doktora podczas Giełdy (p)różności dyplom i nagrodę książkową otrzymali: za zajęcia pierwszego miejsca dr Alicja Bondar-Korzeniecka (UWB), drugiego miejsca dr Maksymilian Chutorański (Usz). W kategorii najlepsze wystąpienie magistra pierwsze miejsce otrzymał mgr Mateusz Szafrański (UMK), natomiast drugie miejsce zdobyła mgr Barbara Walas (UZ). Osobom najbardziej aktywnym w dyskusjach wręczono wyróżnienia; Twórczy szum przyznano dr. Aleksandrowi Cywińskiemu, a Twórczy szumek dr. Maksymilianowi Chutorańskiemu. Coroczne wykupienie dyplomów uczestnictwa odbyło się poprzez krótkie, humorystyczne występy lub czytanie autorskich fraszko-limeryków przez uczestników.

Ceremonia zakończenia XXXII LSMP obfitowała w częste wzruszenia, refleksje i niespodzianki artystyczno-nostalgiczne. Na ręce zastępczyni kierownik naukowej LSMP dr hab. Ewy Bochno, prof. UZ oraz dr Magdaleny Zapotocznej zostały złożone podziękowania za zaangażowanie całego komitetu w organizację i opiekę merytoryczną nad tegoroczną Szkołą. Wyrazy wdzięczności skierowano również do władz uczelni i wydziału, które reprezentował dziekan dr hab. Marek Furmanek, prof. UZ, a także pracowników biorących czynny udział w Szkole. 
Kierownik naukowa LSMP prof. Maria Dudzikowa opuściła obrady trzeciego dnia Szkoły, późnym wieczorem 19 września. Pożegnanie miało niezwykle przejmujący i symboliczny charakter. Drogę do samochodu wyznaczył korowód zgromadzonych przed hotelem młodych uczestników i profesorów, którzy trzymali w dłoniach pochodnie i przy wtórze rozmaitych dźwięków kołatek śpiewali „ależ owszem, ależ tak, tak, tak!”. Tego wyjątkowego, wrześniowego wieczoru płomienie pochodni były świadectwem tlącej się nadziei na powtórne spotkanie z profesor MD. Około pięciu tygodni po zakończeniu XXXII LSMP, a po prawie dwóch latach walki z chorobą nowotworową, nadeszła niezwykle smutna wiadomość o śmierci prof. Marii Dudzikowej.

Pochodnia to symbol nieśmiertelności. Ogień niesie oczyszczenie, daje ciepło i światło, które rozjaśnia drogę. „Nieście więc wiedzy pochodnię na czele” napisał Adam Asnyk w utworze zatytułowanym Do młodych. Poetycki apel do młodego pokolenia - ludzi zaangażowanych, gotowych do pracy nad sobą, pamiętających o dorobku przodków. Profesor Maria Dudzikowa pozostawia nam idee, wartości i standardy zobowiązujące „naukową wspólnotę uczących się” do ich kontynuacji.

\section{Do mlodych}

Adam Asnyk (1880)

Szukajcie prawdy jasnego plomienia!

Szukajcie nowych, nie odkrytych dróg...

Za każdym krokiem w tajniki stworzenia

Coraz się dusza ludzka rozprzestrzenia,

I większym staje się Bóg!

Choć otrzaśniecie kwiaty barwnych mitów,

Choć rozproszycie legendowy mrok,

Choć mgłe urojeń zedrzecie z błękitów,

Ludziom niebiańskich nie zbraknie zachwytów,

Lecz dalej sięgnie ich wzrok.

Każda epoka ma swe własne cele

I zapomina o wczorajszych snach... 
Nieście więc wiedzy pochodnię na czele

I nowy udzial bierzcie w wieków dziele,

Przyszłości podnoście gmach!

Ale nie depczcie przesztości ołtarzy,

Choć macie sami doskonalsze wznieść;

Na nich się jeszcze święty ogień żarzy,

I mitość ludzka stoi tam na straży,

I wy winniście im cześćc!

Ze światem, który w ciemność już zachodzi

Wraz z cała tęcza idealnych snów,

Prawdziwa madrość niechaj was pogodzi -

I wasze gwiazdy, o zdobywcy młodzi,

W ciemnościach pogasna znów! 